Check for updates

Cite this: RSC Adv., 2019, 9, 38271

Received 21st September 2019

Accepted 14th November 2019

DOI: $10.1039 / c 9 r a 07660 c$

rsc.li/rsc-advances

\title{
Facile synthesis of perovskite $\mathrm{CeMnO}_{3}$ nanofibers as an anode material for high performance lithium- ion batteries
}

\author{
Bin Yue, $\uparrow$ Quanli Hu, (D) $\dagger^{*}$ Lei Ji, Yin Wang and Jinghai Liu (D)*
}

\begin{abstract}
A facile synthesis of perovskite-type $\mathrm{CeMnO}_{3}$ nanofibers as a high performance anode material for lithiumion batteries was demonstrated. The nanofibers were prepared by the electrospinning technique. The characterization of $\mathrm{CeMnO}_{3}$ nanofibers was carried out by X-ray diffraction, Fourier transform infrared spectroscopy, scanning electron microscopy (SEM), transmission electron microscopy (TEM), and X-ray photoelectron spectroscopy. SEM images manifested nanofibers with a diameter of $470 \mathrm{~nm}$ having a rough surface with a porous structure. TEM images were consistent with the observations from the SEM images. The electrochemical properties of $\mathrm{CeMnO}_{3}$ perovskite in lithium-ion batteries were investigated. The $\mathrm{CeMnO}_{3}$ anode exhibited a discharge capacity of $2159 \mathrm{~mA} \mathrm{~h} \mathrm{~g}{ }^{-1}$ with a coulombic efficiency of $93.79 \%$. In addition, a high cycle stability and a capacity of $276 \mathrm{~mA} \mathrm{~h} \mathrm{~g}^{-1}$ at the current density of $1000 \mathrm{~mA} \mathrm{~g}^{-1}$ can be effectively maintained due to the high $\mathrm{Li}^{+}$conductivity in the $\mathrm{CeMnO}_{3}$ anode. This study could provide an efficient and potential application of perovskite-type $\mathrm{CeMnO}_{3}$ nanofibers in lithium-ion batteries.
\end{abstract}

\section{Introduction}

With the rapid development of science and technology, electronic equipment has also undergone exponential evolution during the past 5 decades. The electrical power unit (EPU) makes people's life more convenient. In the meantime, it leads to many serious issues, such as the damage and pollution of the environment. It is extremely urgent to develop environmentally friendly and efficient energy storage systems for current electric vehicles. ${ }^{1}$ The lithium-ion battery (LIB) is one of the most desired electrochemical energy storage devices thanks to its high voltage, high energy density, small self-discharge, long cycle retention, no-memory effect, and eco-friendliness. At present, graphite is the most common anode material for the commercial LIBs with a relatively low theoretical specific capacity of $372 \mathrm{~mA} \mathrm{~h} \mathrm{~g}{ }^{-1} .^{2}$ The slow evolution of electrode materials seriously restricts the further development of LIBs commercialization. Therefore, in the cause of meeting market requirements, it is an emergency to develop anode materials having high energy density, high safety, and long cycle life for high performance energy storage system. ${ }^{3-9}$

So far, many researchers have studied a variety of materials for high performance LIB anodes. Silicon has attracted much

Nano Innovation Institute (NII), Inner Mongolia Key Lab of Carbon Nanomaterials, College of Chemistry and Chemical Engineering, Inner Mongolia University for Nationalities (IMUN), Tongliao, 028-000, People's Republic of China. E-mail: huquanly@hotmail.com; jhliu2008@sinano.ac.cn

$\dagger$ These authors contributed equally to this work. attention thanks to the ultra-high theoretical specific capacity $\left(4200 \mathrm{~mA} \mathrm{~h} \mathrm{~g}^{-1}\right)$. However, there is a critical issue that the large volume expansion ratio limits its application in LIBs. ${ }^{10-12}$ It was reported that transition metal oxides exhibited favorable electrochemical performances as anode materials for LIBs, such as $\mathrm{Co}_{x} \mathrm{O}_{y},{ }^{13-16} \mathrm{Fe}_{3} \mathrm{O}_{4},{ }^{17,18} \mathrm{Ni}_{x} \mathrm{O}_{y},{ }^{19,20}$ and $\mathrm{Mn}_{x} \mathrm{O}_{y}{ }^{21,22}$ Specially, $\mathrm{Mn}_{x} \mathrm{O}_{y}$ is regarded as a promising material for LIB anode owing to abundance, low cost, and eco-friendliness. ${ }^{23}$ But low conductivity gives rise to structural collapse of the anode material during $\mathrm{Li}^{+}$ion insertion/deinsertion, leading to poor cycle stability. ${ }^{24-27}$ For purpose of solving this critical issue, researchers focused on improving the conductivity of anode material. Graphene-wrapped $\mathrm{MnO}_{2}$ nanoribbons synthesized by hydrothermal reaction showed a specific capacity of $890 \mathrm{~mA} \mathrm{~h} \mathrm{~g}{ }^{-1}$ at a current density of $100 \mathrm{~mA} \mathrm{~g}^{-1} .^{28}$ The chemically fabricated coaxial $\mathrm{MnO}_{2} / \mathrm{CNT}$ nanocomposites presented a specific capacity of $474 \mathrm{~mA} \mathrm{~h} \mathrm{~g}{ }^{-1}$ at a current density of $1600 \mathrm{~mA} \mathrm{~g}^{-1} \cdot{ }^{29}$ In addition, $\mathrm{MnO}_{2} @ \mathrm{TiO}_{2}$ nanocomposites with core@shell structure, which greatly improved the anode stability, presented a specific capacity of $938 \mathrm{~mA} \mathrm{~h} \mathrm{~g}^{-1}$ at a current density of $300 \mathrm{~mA} \mathrm{~g}^{-1} \cdot{ }^{30} \mathrm{As}$ a stable oxide, $\mathrm{CeO}_{2}$ is used in the fields of electronic devices, catalysis, and electrochemical energy storage due to its favorably thermal stability, catalytic activity, and suitable valence states. ${ }^{31-33}$ The charge mass transfer resistance is greatly reduced, and the electrochemical performance is highly improved by constructing ternary perovskite structure. ${ }^{34}$ Till now, the application of $\mathrm{CeMnO}_{3}$ nanofibers with perovskite structure in lithium-ion batteries has not been studied. 
In this work, a facile synthesis of perovskite-type $\mathrm{CeMnO}_{3}$ nanofibers by electrospinning technique as high performance anode material for lithium-ion batteries was demonstrated. This technique is easy to operate and applicable to synthesize many kinds of nanomaterials. Those nanofibers showed rough surface with mesoporous structure. The surface area and pore volume of $\mathrm{CeMnO}_{3}$ are $108.772 \mathrm{~m}^{2} \mathrm{~g}^{-1}$ and $0.176 \mathrm{~cm}^{3} \mathrm{~g}^{-1}$, respectively. The high surface area and mesoporous structure facilitate the penetration of electrolyte and the diffusion of $\mathrm{Li}^{+}$ to the active electrode material. $\mathrm{CeMnO}_{3}$ anode exhibited a discharge capacity of $2159 \mathrm{~mA} \mathrm{~h} \mathrm{~g}{ }^{-1}$ with the coulombic efficiency of $93.79 \%$. And a high reversible capacity of $395 \mathrm{~mA} \mathrm{~h} \mathrm{~g}^{-1}$ at $200 \mathrm{~mA} \mathrm{~g}^{-1}$ for $\mathrm{CeMnO}_{3}$ can be obtained even at a high discharge rate of $1000 \mathrm{~mA} \mathrm{~g}^{-1}$ after 60 cycles. The perovskite $\mathrm{CeMnO}_{3}$ with nanofiber-like structure exhibits favorable electrochemical behaviors. The layered structure from $\mathrm{Mn}-\mathrm{O}$ octahedra in perovskite facilitates the insertion and extraction of $\mathrm{Li}^{+}$. In addition, $\mathrm{CeMnO}_{3}$ with perovskite structure improves the diffusion of $\mathrm{Li}^{+}$, alleviates the structure collapse resulting from $\mathrm{Li}^{+}$insertion and extraction, and enhances the cycle stability. It indicates the potential application of perovskite-type $\mathrm{CeMnO}_{3}$ nanofibers for lithium-ion batteries.

\section{Experimental}

The $\mathrm{CeMnO}_{3}$ nanofibers were fabricated by effective electrospinning technique at room temperature and subsequent calcination process at $500{ }^{\circ} \mathrm{C}$. Cerium nitrate hexahydrate $\left(\mathrm{Ce}\left(\mathrm{NO}_{3}\right)_{3} \cdot 6 \mathrm{H}_{2} \mathrm{O}, 1.086 \mathrm{~g}\right.$ ) and manganese acetate (MnAc, 0.4326 $\mathrm{g})$ were served as the sources of $\mathrm{Ce}$ and $\mathrm{Mn}$. Polyvinylpyrrolidone (PVP, $M_{\mathrm{w}} \approx 1300000,2.25 \mathrm{~g}$ ) was worked as nanofiber template. $N, N$-dimethylformamide (DMF, $16.5 \mathrm{~mL}$ ) was used as the solvent. The precursor solution was prepared by mixing $\mathrm{Ce}\left(\mathrm{NO}_{3}\right)_{3} \cdot 6 \mathrm{H}_{2} \mathrm{O}, \mathrm{MnAc}$, and PVP into DMF, and stirring for $14 \mathrm{~h}$. Then, this brownish solution was loaded into a $10 \mathrm{~mL}$ plastic syringe and electrospun at $18 \mathrm{kV}$ with the distance between a collector and a needle of $15 \mathrm{~cm}$ at the flow rate of $0.75 \mathrm{~mL} \mathrm{~h}^{-1}$. The as-spun $\mathrm{Ce}\left(\mathrm{NO}_{3}\right)_{3}-\mathrm{MnAc} / \mathrm{PVP}$ nanofibers were dried at $55{ }^{\circ} \mathrm{C}$ overnight in a vacuum oven. The calcination process was performed at $500{ }^{\circ} \mathrm{C}$ for $2 \mathrm{~h}$ with a heating rate of $1{ }^{\circ} \mathrm{C} \min ^{-1}$ in a muffle furnace under air atmosphere. In addition, control samples of $\mathrm{CeO}_{2}$ and $\mathrm{Mn}_{3} \mathrm{O}_{4}$ nanofibers was fabricated under the same condition without $\mathrm{Mn}$ and Ce source, respectively.

Brunauer-Emmett-Teller and Barrett-Joyner-Halenda (BET and BJH, Quadrasorbsi) methods were performed to determine the specific surface area and pore size distribution of $\mathrm{CeMnO}_{3}$ NFs. The crystal structures of $\mathrm{CeMnO}_{3}, \mathrm{CeO}_{2}$, and $\mathrm{Mn}_{3} \mathrm{O}_{4}$ were studied using X-ray diffractometer (XRD, Bruker D8 Focus) at room temperature. The Fourier transforms infrared (FT-IR, Bruker Vector 22 Spectrometer) spectra of as-spun $\mathrm{Ce}\left(\mathrm{NO}_{3}\right)_{3}-$ $\mathrm{MnAc} / \mathrm{PVP}$ NFs and $\mathrm{CeMnO}_{3} \mathrm{NFs}$ were detected in the range from 4000 to $400 \mathrm{~cm}^{-1}$ using $\mathrm{KBr}$ as dispersant. The microstructures and morphologies of $\mathrm{CeMnO}_{3} \mathrm{NFs}$ were analyzed on a scanning electron microscope (SEM, Hitachi S-4800, $20 \mathrm{kV}$ ) and a transmission electron microscope (TEM, JEOL JEM 2100, $200 \mathrm{kV}$ ). X-ray photoelectron spectroscopy (XPS, Al Ka, Thermo
Escalab 250) was carried out to analyze the valence states of $\mathrm{CeMnO}_{3} \mathrm{NFs}$.

The electrochemical characteristics of $\mathrm{CeO}_{2}, \mathrm{Mn}_{3} \mathrm{O}_{4}$, and $\mathrm{CeMnO}_{3}$ were performed by assembling 2032-type coin cells. Electrodes were fabricated by adding $\mathrm{CeMnO}_{3}$ (80 wt\%), acetylene black (10 wt \%), and polytetrafluoroethylene (PTFE, $10 \mathrm{wt} \%$ ) into $N$-methyl-2-pyrrolidone (NMP) to form a homogeneous slurry. Then, the slurry was roll-pressed on aluminum foil and dried at $60{ }^{\circ} \mathrm{C}$ overnight in a vacuum oven. Electrochemical cells were fabricated with an active material as an anode, a lithium foil as a cathode, a Celgard 2400 microporous membrane as a separator, and $1 \mathrm{~mol} \mathrm{~L}^{-1} \mathrm{LiPF}_{6}$ as electrolyte solution. Those cells were assembled in an Ar-filled glove box with both oxygen and moisture content below 1 ppm (Vigor, Co. Ltd., Suzhou, China). Galvanostatic charge/discharge behaviors of $\mathrm{CeO}_{2}$, $\mathrm{Mn}_{3} \mathrm{O}_{4}$, and $\mathrm{CeMnO}_{3}$ were detected using a battery testing system (Land Co. Ltd., Wuhan, China) with a voltage window of 0.01-3.0 V vs. $\mathrm{Li} / \mathrm{Li}^{+}$for setting current rates. Electrochemical impedance spectroscopy (EIS) measurements were implemented via an electrochemical workstation (Bio-Logic, Co. Ltd, Seyssinet-pariset, France). The AC perturbation signal was $5 \mathrm{mV}$ with the frequency ranging from 0.01 to $10^{5} \mathrm{~Hz}$. Impedance data were analyzed using an electrochemical impedance software of EC-Lab.

\section{Results and discussion}

According to BET and BJH methods, the surface area and pore volume of $\mathrm{CeMnO}_{3}$ are $108.772 \mathrm{~m}^{2} \mathrm{~g}^{-1}$ and $0.176 \mathrm{~cm}^{3} \mathrm{~g}^{-1}$, respectively. In addition, the average pore diameter is $4.89 \mathrm{~nm}$, indicating the mesoporous structure. The high surface area is of great importance to facilitate the diffusion of $\mathrm{Li}^{+}$from electrolyte to electrode material. The schematic illustration of $\mathrm{CeMnO}_{3}$ with perovskite structure is depicted as shown in Fig. 1. The crystal structures of $\mathrm{CeMnO}_{3}, \mathrm{CeO}_{2}$, and $\mathrm{Mn}_{3} \mathrm{O}_{4}$ were recorded by XRD pattern which are displayed in Fig. 2(a). For $\mathrm{CeO}_{2}$ sample, the diffraction peaks are assigned to (111), (200), (220), (311), (222), (400), (331) and (420) planes of cubic fluorite $\mathrm{CeO}_{2}$. The XRD pattern matches well with the JCPDS card (34-0394) implying a face-centered cubic fluorite structure of $\mathrm{CeO}_{2}$ with space group $F m \overline{3} m .{ }^{35}$ The diffraction peaks of $\mathrm{Mn}_{3} \mathrm{O}_{4}$ are related to (112), (200), (103), (211), (004), (220), (105), (303), (321), (224), and (400), which are agree with the JCPDS card (24-0734). ${ }^{36}$ For $\mathrm{CeMnO}_{3} \mathrm{NFs}$, the diffraction peaks slightly transfer to higher Bragger angle and the intensities become weaker and broader. The four major diffraction peaks of $\mathrm{CeMnO}_{3}$ correspond to the (111) plane of $\mathrm{CeO}_{2}$ and the (022), (02-2), and (220) planes of $\mathrm{CeMnO}_{3} \cdot{ }^{37-39}$ The FT-IR spectra of as-spun $\mathrm{Ce}\left(\mathrm{NO}_{3}\right)_{3}-\mathrm{MnAc} / \mathrm{PVP}$ NFs and $\mathrm{CeMnO}_{3}$ NFs are depicted in Fig. 2(b). The peaks at 3434 and $1625 \mathrm{~cm}^{-1}$ correspond to the stretching and vibration mode of $\mathrm{O}-\mathrm{H}$. The peak at $2919 \mathrm{~cm}^{-1}$ is assigned to the stretching $\mathrm{C}-\mathrm{H}$ vibration of alkyl groups. The peaks at 1651 , 1438, and $1259 \mathrm{~cm}^{-1}$ are ascribed to $\mathrm{C}=\mathrm{O}, \mathrm{C}-\mathrm{H}$, and $\mathrm{C}-\mathrm{N}$ functional groups. ${ }^{\mathbf{4 0 - 4 2}}$ Those peaks from $\mathrm{Ce}\left(\mathrm{NO}_{3}\right)_{3}-\mathrm{MnAc} / \mathrm{PVP}$ NFs after calcination were weakened or vanished. The peaks at 520 and $433 \mathrm{~cm}^{-1}$ refer to the metal-oxygen stretching vibrations of $\mathrm{Ce}-\mathrm{O}$ and $\mathrm{Mn}-\mathrm{O} .^{40,43}$ 


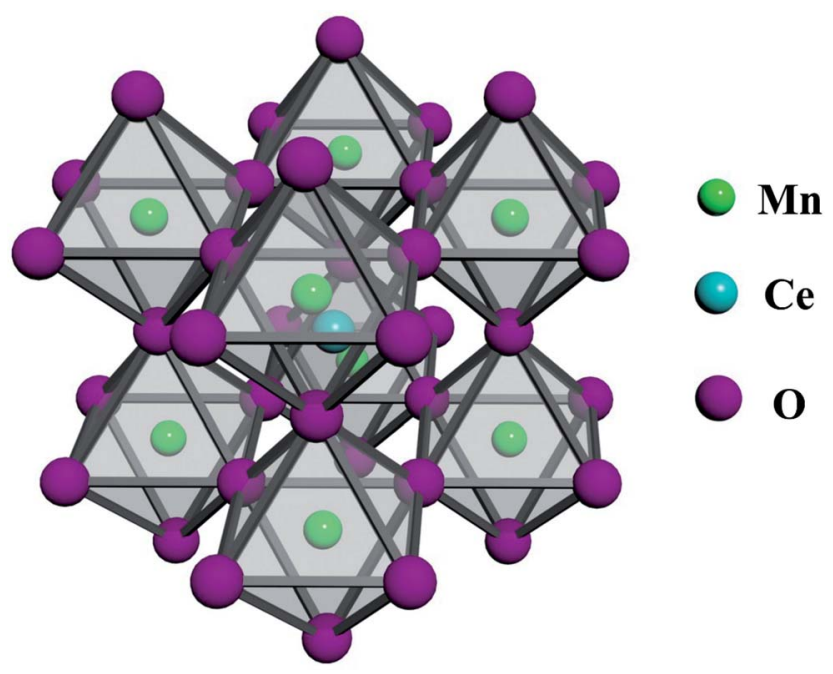

Fig. 1 The schematic structure of perovskite-type $\mathrm{CeMnO}_{3}$.

The SEM images of $\mathrm{Ce}\left(\mathrm{NO}_{3}\right)_{3}-\mathrm{MnAc} / \mathrm{PVP}$ NFs and $\mathrm{CeMnO}_{3}$ NFs are shown in Fig. 3. The morphology of the precursor NFs was beige and uniform with the diameter of $550 \mathrm{~nm}$. After calcination, the surfaces of $\mathrm{CeMnO}_{3} \mathrm{NFs}$ were no longer smooth, and those nanofibers were broken up into sections which could be originated from the combustion of PVP, the decomposition of nitrate and acetate, and the crystallization of Ce-Mn-O. ${ }^{35,44}$ The diameter was reduced to $470 \mathrm{~nm}$. The nanofiber-like structure provides a short diffusion path for ion transport. ${ }^{45}$ The detailed morphology and structure of an individual $\mathrm{CeMnO}_{3} \mathrm{NF}$ were further investigated by TEM micrographs (Fig. 4). The TEM images indicate that the diameter of the individual nanofiber is $470 \mathrm{~nm}$. The nanofiber shows rough surface with porous structure, which is greatly agree with the observations from SEM images.

The chemical bonding states and compositions of the fabricated $\mathrm{CeMnO}_{3}$ NFs have been detected as shown in Fig. 5 . In the survey spectrum, the peaks of O 1s, Mn 2P, Ce 3d, and Ce $4 \mathrm{~d}$ have been shown in Fig. 5(a). Ce $3 \mathrm{~d}$ spectrum was analyzed as shown in Fig. 5(b). Six major peaks can be observed, including three peaks at $882.32,888.73$, and $898.1 \mathrm{eV}$ corresponding to the component of Ce $3 \mathrm{~d}_{5 / 2}$, and three peaks at 900.71, 907.33, and
$916.49 \mathrm{eV}$ being assigned to the component of Ce $3 \mathrm{~d}_{5 / 2}{ }^{46}$ It confirms the existence of $\mathrm{Ce}^{4+}$ in the $\mathrm{CeMnO}_{3} \mathrm{NFs}^{47}$ The detailed information of Ce $3 \mathrm{~d}$ spectra is shown in Table 1 . The binding energy peak at $108.6 \mathrm{eV}$ with the component of Ce $4 \mathrm{~d}_{5 / 2}$ from final state of $4 \mathrm{~d}^{9} 4 \mathrm{f}^{1}+4 \mathrm{~d}^{9} 4 \mathrm{f}^{2}$ can be clearly seen in Ce $4 \mathrm{~d}$ spectrum (Fig. 5(c)), indicating the presence of $\mathrm{Ce}^{3+} \cdot{ }^{49} \mathrm{Mn} 2 \mathrm{p}$ spectrum is exhibited in Fig. 5(d). Two major peaks at 642.18 and $653.99 \mathrm{eV}$ are assigned to the component of $\mathrm{Mn} 2 \mathrm{p}_{3 / 2}$ and Mn $2 \mathrm{p}_{1 / 2}$, respectively, implying the existence of $\mathrm{Mn}^{3+} \cdot{ }^{50}$ As shown in Fig. 5(e), the main O 1s peaks at 529.73 and $530.90 \mathrm{eV}$ are related to the oxygen atoms in the lattice and the oxygen ions of the oxygen deficient region in $\mathrm{CeMnO}_{3} \mathrm{NFs}$, respectively. ${ }^{51}$

To further clarify the electrochemical performances of $\mathrm{CeO}_{2}$, $\mathrm{Mn}_{3} \mathrm{O}_{4}$, and $\mathrm{CeMnO}_{3}$ anodes, $\mathrm{CV}$ curves of electrodes for the 1st, 2nd and 5th cycles were analyzed. In Fig. 6(a), two reduction peaks V1 and V2 located at 0.2 and $0.6 \mathrm{~V}$ are detected in the first scan, which originated from the formation of solid electrolyte interphase (SEI) and the initial reduction of $\mathrm{CeO}_{2}$ to $\mathrm{Ce}\left(\mathrm{CeO}_{2}+\right.$ $\left.4 \mathrm{Li}^{+}+4 \mathrm{e}^{-}=\mathrm{Ce}+2 \mathrm{Li}_{2} \mathrm{O}\right)$, respectively. The oxidation peak at about $2.5 \mathrm{~V}(\mathrm{~V} 3)$ as a result of the reaction between $\mathrm{Ce}$ and $\mathrm{Li}_{2} \mathrm{O}$ $\left(\mathrm{Ce}+2 \mathrm{Li}_{2} \mathrm{O}=\mathrm{CeO}_{2}+4 \mathrm{Li}^{+}+4 \mathrm{e}^{-}\right) .{ }^{52}$ In Fig. 6(b), the major cathodic peaks in the 1st cycle for $\mathrm{Mn}_{3} \mathrm{O}_{4}$ located at 0.2 and $1.35 \mathrm{~V}$. And the peak at $0.2 \mathrm{~V}$ is related to the formation of SEI layer and the reduction of $\mathrm{Mn}_{x} \mathrm{O}_{y}$ with $\mathrm{Li}$ ions, which can be depicted by $\mathrm{Mn}_{3} \mathrm{O}_{4}+8 \mathrm{Li}^{+}+8 \mathrm{e}^{-}=3 \mathrm{Mn}+4 \mathrm{Li}_{2} \mathrm{O} \cdot{ }^{53}$ After five repetitive cycles, the oxidation-reduction peaks decreased slightly, and a good stability can be carefully maintained. As show in Fig. 6(c), compared with $\mathrm{CeO}_{2}$ and $\mathrm{Mn}_{3} \mathrm{O}_{4}, \mathrm{CeMnO}_{3}$ shows relatively different peak positions. The oxidation peaks at 1.2 and $2.4 \mathrm{~V}$ are attributed to the oxidation of $\mathrm{Ce}^{3+}$ and $\mathrm{Mn}^{3+}$, and there is a wide plateau at $0.5-1.0 \mathrm{~V}$, which originates from the reduction of $\mathrm{Mn}^{3+}$ to metallic $\mathrm{Mn} .{ }^{54} \mathrm{~A}$ small $\mathrm{CV}$ curve was shown in the first cycle, which might be due to the super ionconduction of perovskite $\mathrm{CeMnO}_{3}$.

Fig. 7 displays the initial discharge profiles of $\mathrm{CeO}_{2}, \mathrm{Mn}_{3} \mathrm{O}_{4}$, and $\mathrm{CeMnO}_{3}$ anodes. The cells were charged and discharged at a current density of $200 \mathrm{~mA} \mathrm{~g}^{-1}$ in the voltage range of $0.01-$ $3.0 \mathrm{~V}$ versus $\mathrm{Li}^{+} / \mathrm{Li}$. The three fabricated samples exhibit discharge capacities of 338, 592, $2159 \mathrm{~mA} \mathrm{~h} \mathrm{~g}^{-1}$ with coulombic efficiencies of $94.67 \%, 84.63 \%$, and $93.79 \%$, respectively. The
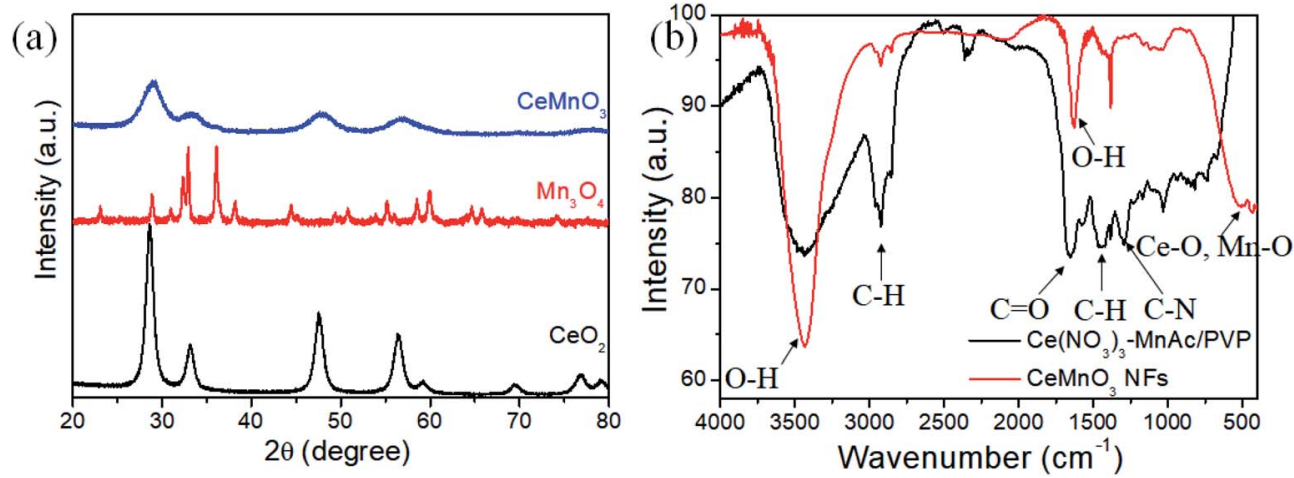

Fig. 2 (a) XRD patterns of $\mathrm{CeO}_{2}, \mathrm{Mn}_{3} \mathrm{O}_{4}$, and $\mathrm{CeMnO}_{3} \mathrm{NFs}$. (b) FT-IR spectra of as-spun $\mathrm{Ce}\left(\mathrm{NO}_{3}\right)_{3}-\mathrm{MnAc} / \mathrm{PVP} \mathrm{NFs}$ and CeMnO 3 NFs. 


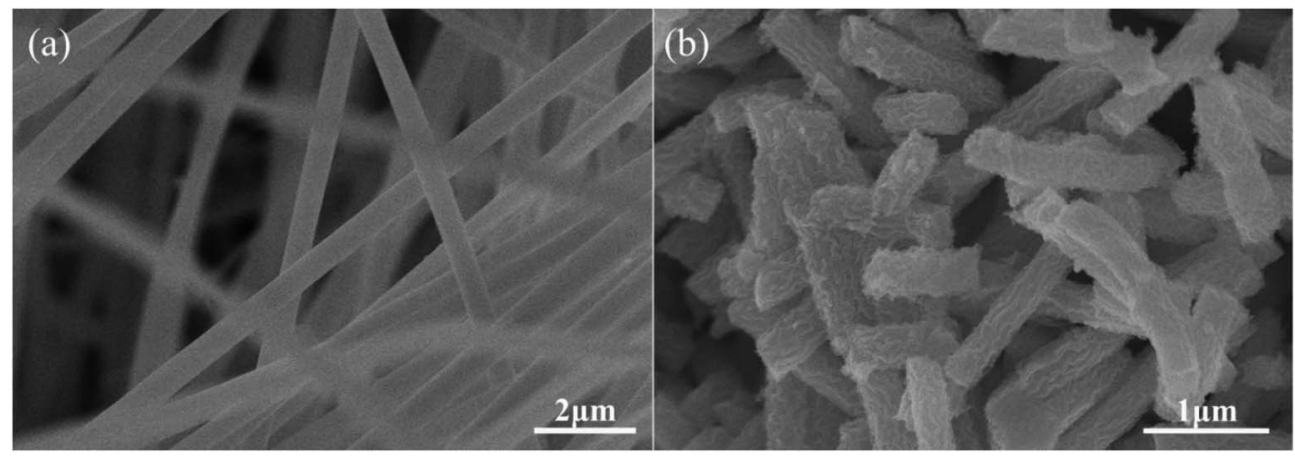

Fig. 3 (a) SEM image of as-spun $\mathrm{Ce}\left(\mathrm{NO}_{3}\right)_{3}-\mathrm{MnAc} / \mathrm{PVP} \mathrm{NFs}$. (b) SEM image of $\mathrm{CeMnO}_{3} \mathrm{NFs}$.

SEI layer formed between electrode and electrolyte leads to the irreversible capacity reduction in the first cycle. ${ }^{55}$ From the discharge curve, $\mathrm{CeO}_{2}$ and $\mathrm{Mn}_{3} \mathrm{O}_{4}$ cells exhibit considerably narrow discharge platforms. However, it is obvious that perovskite $\mathrm{CeMnO}_{3}$ has a relatively stable discharge platform at $0.5 \mathrm{~V}$. As shown in Fig. 1, the layered structure from Mn-O octahedra is constructed by sharing one oxygen atom. Between the layers, the insertion and deinsertion of $\mathrm{Li}^{+}$can achieve from this perovskite structure. ${ }^{33}$ Therefore, $\mathrm{CeMnO}_{3}$ NFs exhibit high reversible capacity compared with the other two samples.

The cycling performances of $\mathrm{CeO}_{2}, \mathrm{Mn}_{3} \mathrm{O}_{4}$, and $\mathrm{CeMnO}_{3}$ anodes under a current density of $200 \mathrm{~mA} \mathrm{~g}^{-1}$ with the voltage ranging from 0.01 to $3.0 \mathrm{~V}$ are presented in Fig. 8. Within 20 cycles, the capacities of the three samples rapidly declined. The discharge specific capacity of $\mathrm{CeO}_{2}$ reduces to lower than $200 \mathrm{~mA} \mathrm{~h} \mathrm{~g}^{-1}$ after ten cycles and that of $\mathrm{Mn}_{3} \mathrm{O}_{4}$ after 20 cycles is about $300 \mathrm{~mA} \mathrm{~h} \mathrm{~g}{ }^{-1}$. Due to the Jahn-Teller effect, $\mathrm{Mn}^{3+}$ is gradually converted into $\mathrm{Mn}^{2+}$ and $\mathrm{Mn}^{4+}$, and then dispersed in the electrolyte, resulting in irreversible capacity reduction after consecutive cycling. A stable capacity can be achieved in $\mathrm{CeMnO}_{3}$ anode. For $\mathrm{CeMnO}_{3}$ anode, after 60 cycles the capacity gradually increases, because the anode undergoes a rapid activation process. ${ }^{56}$ The reaction of $\mathrm{CeMnO}_{3}+\mathrm{Li}_{2} \mathrm{O}=\mathrm{CeO}_{2}+\mathrm{MnO}_{2}$ $+2 \mathrm{Li}^{+}+2 \mathrm{e}^{-}$is gradually strengthened, which further improves the electrochemical performance. Compared with $\mathrm{Mn}_{3} \mathrm{O}_{4}$, the unique perovskite structure of $\mathrm{CeMnO}_{3}$ can improve the diffusion of $\mathrm{Li}^{+}$, alleviate the structure collapse resulting from $\mathrm{Li}^{+}$ insertion and extraction, and improve the cycle stability. ${ }^{33}$ After
200 cycles the capacities of $\mathrm{CeO}_{2}, \mathrm{Mn}_{3} \mathrm{O}_{4}$, and $\mathrm{CeMnO}_{3}$ anode are $175.6,315$ and $322.9 \mathrm{~mA} \mathrm{~h} \mathrm{~g}^{-1}$, respectively. In comparison with common $\mathrm{CeO}_{2}$ with the reversible capacity of $315 \mathrm{~mA} \mathrm{~h} \mathrm{~g}^{-1}$ after 50 cycles, the fabricated $\mathrm{CeMnO}_{3}$ as anode material exhibits more stable cycle life and higher capacity. ${ }^{57}$

Fig. 9 exhibits the rate capabilities of $\mathrm{CeO}_{2}, \mathrm{Mn}_{3} \mathrm{O}_{4}$ and $\mathrm{CeMnO}_{3}$. The three kinds of assembled cells were measured at the current density of $200 \mathrm{~mA} \mathrm{~g}^{-1}$ in the first 10 cycles, and then measured at various current densities ranging from 400 to $1000 \mathrm{~mA} \mathrm{~g}^{-1}$. Among the three samples, $\mathrm{CeMnO}_{3}$ displays the best performance and the highest reversible capacity of $530 \mathrm{~mA} \mathrm{~h} \mathrm{~g}^{-1}$ at the current density of $200 \mathrm{~mA} \mathrm{~g}^{-1}$ after 10 cycles. When the current densities increased, the capacity slightly decreased. Particularly, after discharging at $1000 \mathrm{~mA} \mathrm{~g}^{-1}, \mathrm{CeMnO}_{3}$ anode still presents a reversible discharge capacity of $276 \mathrm{~mA} \mathrm{~h} \mathrm{~g}^{-1}$. Furthermore, an ultra-high reversible capacity of $395 \mathrm{~mA} \mathrm{~h} \mathrm{~g}^{-1}$ at $200 \mathrm{~mA} \mathrm{~g}^{-1}$ can be obtained even at a high discharge rate of $1000 \mathrm{~mA} \mathrm{~g}^{-1}$ after 60 cycles. As illustrated in Fig. 10, the sloping line in the low frequency region is ascribed to Warburg impedance $\left(Z_{\mathrm{w}}\right) .^{58}$ The $R_{\text {ct }}$ value of $\mathrm{CeMnO}_{3}$ is $36.78 \Omega$, which is much lower than those of $\mathrm{CeO}_{2}\left(49.18 \Omega\right.$ ) and $\mathrm{Mn}_{3} \mathrm{O}_{4}(67.99 \Omega)$, implying the high conductivity of the electrochemical system consisting of $\mathrm{CeMnO}_{3}$. In order to further clarify the $\mathrm{Li}^{+}$diffusion performance, the Warburg impedance $\left(Z_{\mathrm{w}}\right)$ for the equivalent circuit (as illustrated in the inset of Fig. 10), the exchange current density $\left(i^{\circ}\right)$ and the diffusion coefficient of $\mathrm{Li}^{+}(D)$ can be depicted by the following equation. ${ }^{59}$

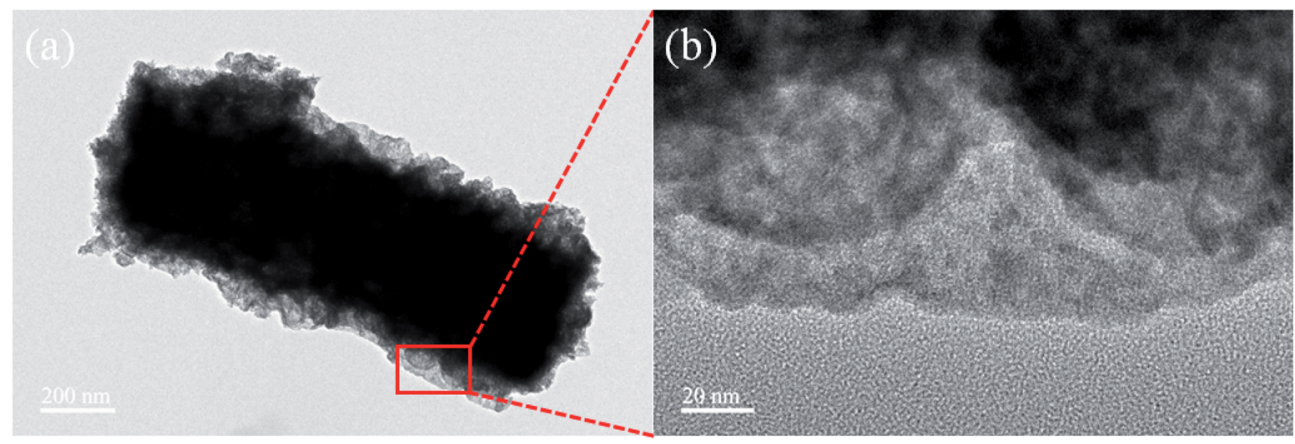

Fig. 4 (a) TEM image and (b) high resolution TEM image of $\mathrm{CeMnO}_{3} \mathrm{NF}$. 

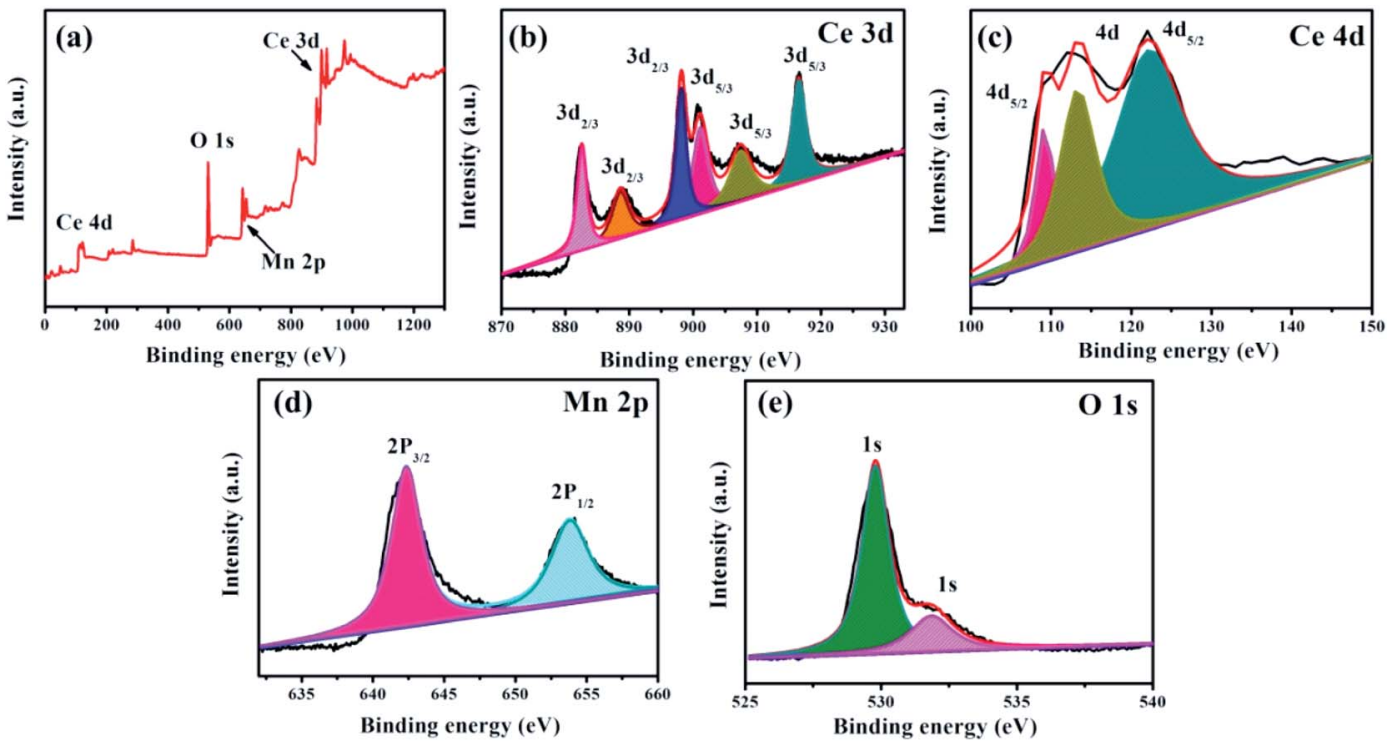

Fig. 5 XPS spectra $\mathrm{CeMnO}_{3} \mathrm{NFs}$ ( (a) survey scan, (b) Ce 3d region, (c) Ce 4d region, (d) Mn 2p region, and (e) O 1s region.

Table 1 Information of the Ce $3 d$ spectrum of XPS ${ }^{46-48}$

\begin{tabular}{llll}
\hline Ce contribution & $\begin{array}{l}\text { Peak position } \\
(\mathrm{eV})\end{array}$ & Peak characteristics & Final state \\
\hline $\mathrm{Ce}(\mathrm{Iv})$ & 882.32 & $3 \mathrm{~d}_{5 / 2}$ & $3 \mathrm{~d}^{9} 4 \mathrm{f}^{2}$ \\
$\mathrm{Ce}(\mathrm{Iv})$ & 888.73 & $3 \mathrm{~d}_{5 / 2}$ & $3 \mathrm{~d}^{9} 4 \mathrm{f}^{1}$ \\
$\mathrm{Ce}(\mathrm{Iv})$ & 898.1 & $3 \mathrm{~d}_{5 / 2}$ & $3 \mathrm{~d}^{9} 4 \mathrm{f}^{0}$ \\
$\mathrm{Ce}(\mathrm{Iv})$ & 900.71 & $3 \mathrm{~d}_{3 / 2}$ & $3 \mathrm{~d}^{9} 4 \mathrm{f}^{2}$ \\
$\mathrm{Ce}(\mathrm{Iv})$ & 907.33 & $3 \mathrm{~d}_{3 / 2}$ & $3 \mathrm{~d}^{9} 4 \mathrm{f}^{1}$ \\
$\mathrm{Ce}(\mathrm{Iv})$ & 916.49 & $3 \mathrm{~d}_{3 / 2}$ & $3 \mathrm{~d}^{9} 4 \mathrm{f}^{0}$ \\
\hline
\end{tabular}

$$
\begin{gathered}
|Z|=R_{\mathrm{e}}+R_{\mathrm{ct}}+\sigma \omega^{-1 / 2} \\
D=\frac{R^{2} T^{2}}{2 A^{2} n^{4} F^{4} C^{2} \sigma^{2}} \\
i^{\circ}=\frac{R T}{n F R_{\mathrm{ct}}}
\end{gathered}
$$

where, $\omega$ is the angular frequency, $R$ is ideal gas constant, $n$ is number of transfer charge, $F$ is the Faraday constant, and $C$ is the concentration of $\mathrm{Li}^{+} . \sigma$ is the Warburg coefficient which can be calculated from the slope of the Bode plot (as show in

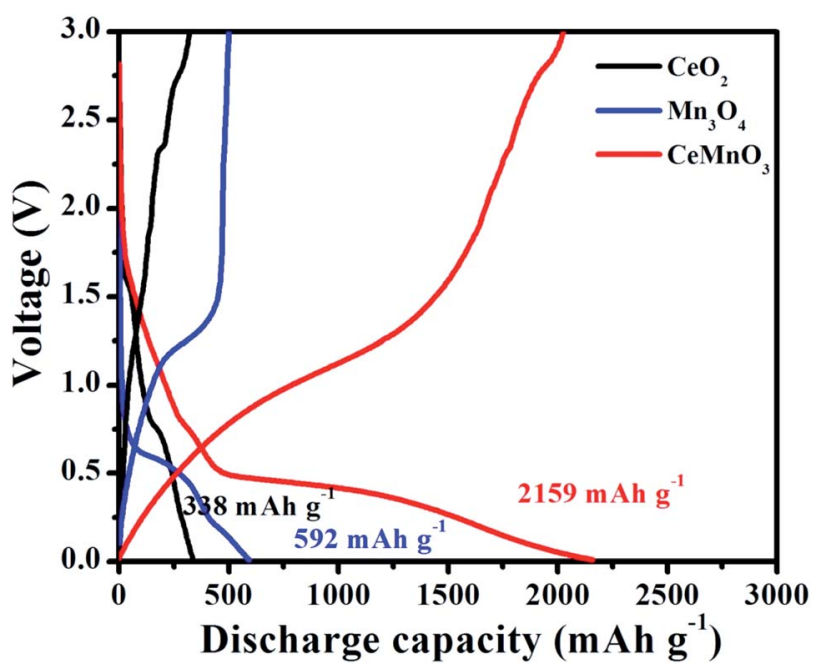

Fig. 7 The initial charge-discharge profiles of $\mathrm{CeO}_{2}, \mathrm{Mn}_{3} \mathrm{O}_{4}$, and $\mathrm{CeMnO}_{3}$ in the voltage of $0.01-3.0 \mathrm{~V}$.

Fig. 11). $\mathrm{CeMnO}_{3}$ exhibits the highest $\mathrm{Li}^{+}$diffusion coefficient of $6.7261 \times 10^{-16} \mathrm{~cm}^{2} \mathrm{~s}^{-1}$. It confirms that $\mathrm{CeMnO}_{3}$ anode exhibits a favorable $\mathrm{Li}^{+}$diffusion performance. The detailed
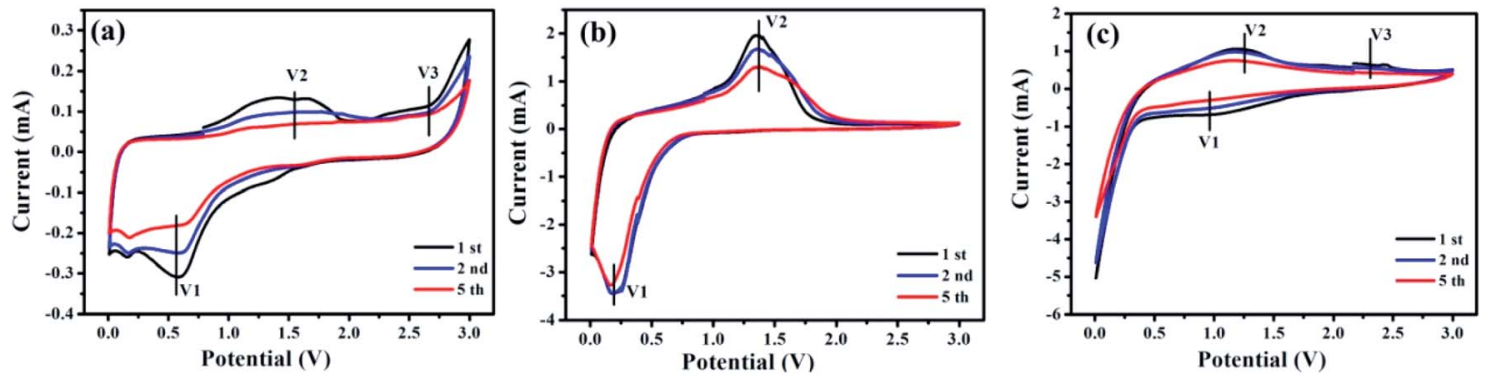

Fig. $6 \mathrm{CV}$ curves of electrodes for 1 st, 2 nd and 5 th cycles at a scan rate of $0.05 \mathrm{mV} \mathrm{s}^{-1}$ of (a) $\mathrm{CeO}_{2}$, (b) $\mathrm{Mn}_{3} \mathrm{O}_{4}$, and (c) $\mathrm{CeMnO}_{3}$. 


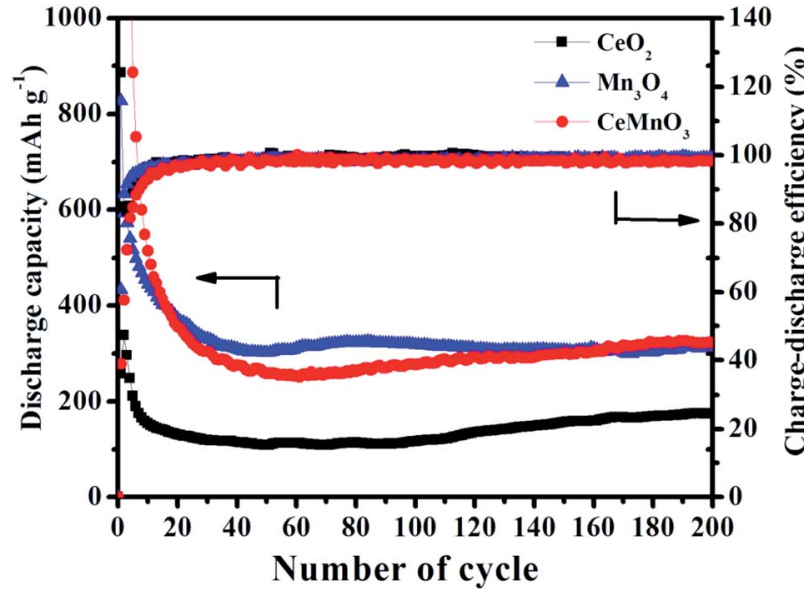

Fig. 8 The cycle capabilities of $\mathrm{CeO}_{2}, \mathrm{Mn}_{3} \mathrm{O}_{4}$, and $\mathrm{CeMnO}_{3}$ at $200 \mathrm{~mA} \mathrm{~g}^{-1}$ in the voltage range of $0.01-3.0 \mathrm{~V}$.

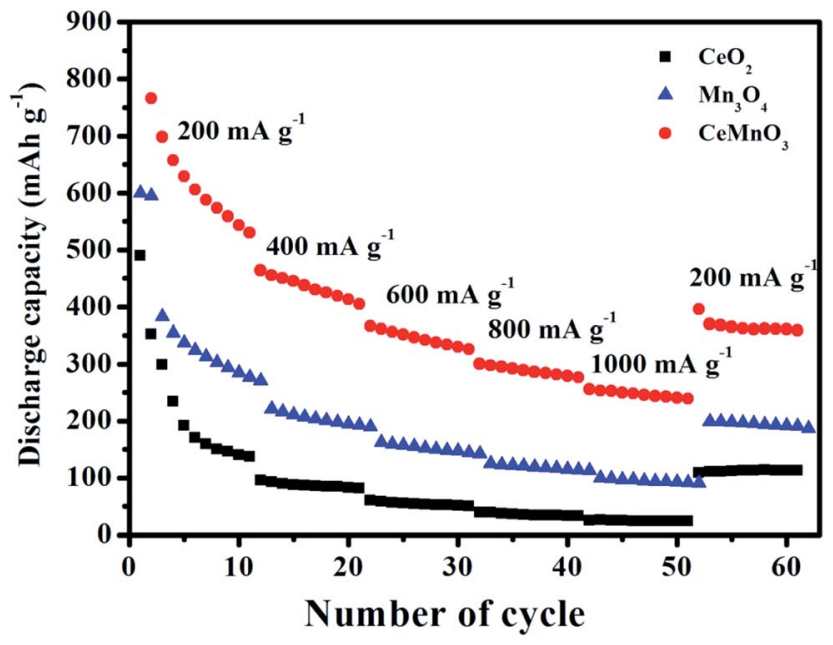

Fig. 9 Rate performance of as-prepared $\mathrm{CeO}_{2}, \mathrm{Mn}_{3} \mathrm{O}_{4}$, and $\mathrm{CeMnO}_{3}$.

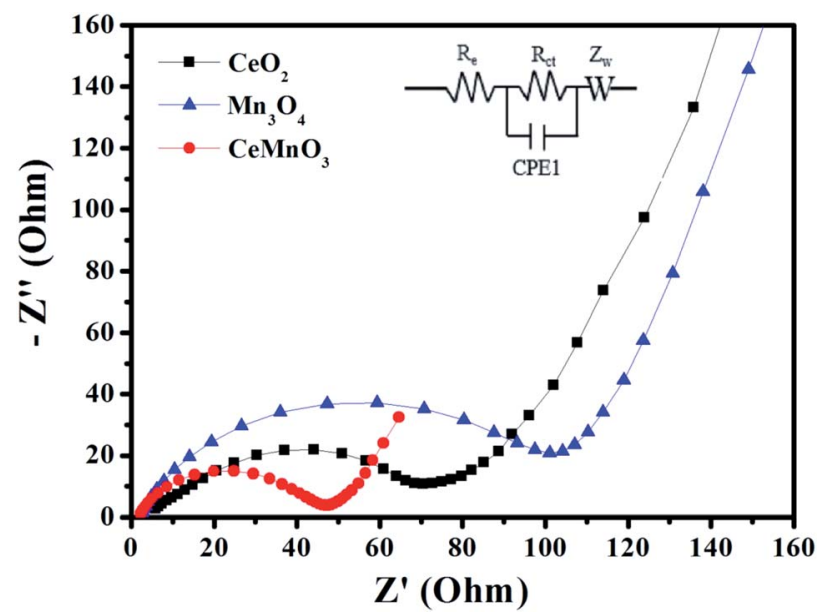

Fig. 10 Impedance spectra of $\mathrm{CeO}_{2}, \mathrm{Mn}_{3} \mathrm{O}_{4}$, and $\mathrm{CeMnO}_{3}$ at open circuit voltage. Inset: equivalent circuit corresponding to the impedance diagrams.

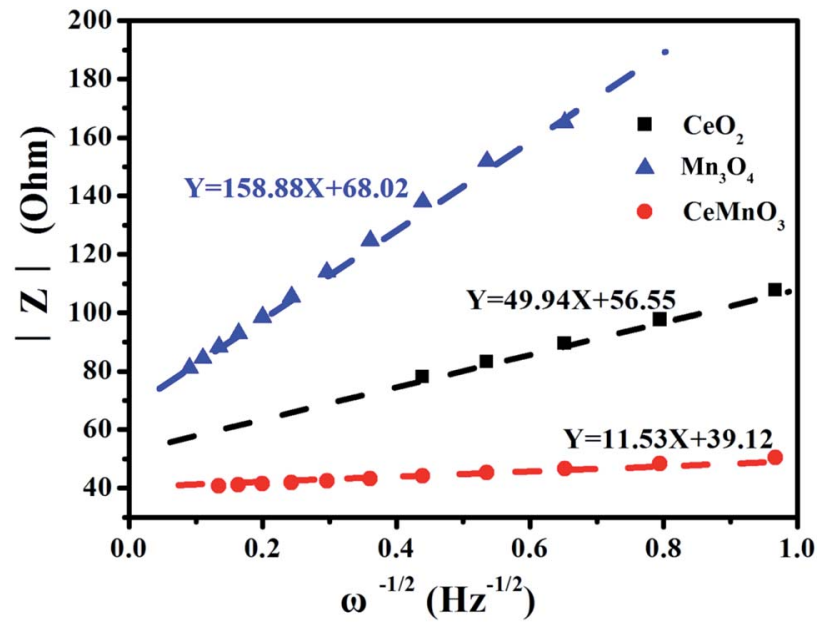

Fig. 11 Fitting line of the $|Z|$ vs. $\omega^{-1 / 2}$ relationship of $\mathrm{CeO}_{2}, \mathrm{Mn}_{3} \mathrm{O}_{4}$, and $\mathrm{CeMnO}_{3}$

Table 2 Electrochemical impedance parameters of $\mathrm{CeO}_{2}, \mathrm{Mn}_{3} \mathrm{O}_{4}$, and $\mathrm{CeMnO}_{3}$

\begin{tabular}{lllcll} 
Sample & $R_{\mathrm{e}}(\Omega)$ & $R_{\text {ct }}(\Omega)$ & $\sigma\left(\Omega \mathrm{s}^{-0.5}\right)$ & $D\left(\mathrm{~cm}^{2} \mathrm{~s}^{-1}\right)$ & $\left.i^{\circ}(\mathrm{mA} \mathrm{cm})^{2}\right)$ \\
\hline $\mathrm{CeO}_{2}$ & 7.669 & 49.18 & 49.94 & $3.5876 \times 10^{-17}$ & $5.2134 \times 10^{-4}$ \\
$\mathrm{Mn}_{3} \mathrm{O}_{4}$ & 2.99 & 67.99 & 158.88 & $3.5423 \times 10^{-18}$ & $3.8293 \times 10^{-4}$ \\
$\mathrm{CeMnO}_{3}$ & 2.596 & 36.78 & 11.53 & $6.7261 \times 10^{-16}$ & $7.0787 \times 10^{-3}$
\end{tabular}

electrochemical impedance parameters of $\mathrm{CeO}_{2}, \mathrm{Mn}_{3} \mathrm{O}_{4}$, and $\mathrm{CeMnO}_{3}$ anodes were summarized in Table 2.

The perovskite $\mathrm{CeMnO}_{3}$ with nanofiber-like structure present favorable electrochemical behaviors. The perovskite structure facilitates the insertion of $\mathrm{Li}^{+}$into Ce-site vacancies and stabilize the cycling performance after the initial discharge process. ${ }^{60}$ The nanofiber-like structure can effectively improve the contact area between electrolyte and anode and shorten the path of $\mathrm{Li}^{+}$entering anode material, thus reducing the electrochemical impedance of the material. ${ }^{61}$

\section{Conclusions}

Perovskite-type $\mathrm{CeMnO}_{3}$ nanofibers as high performance anode material for lithium-ion batteries was effectively synthesized by electrospinning process. These nanofibers with a diameter of $470 \mathrm{~nm}$ present rough surface with mesoporous structure. The electrochemical properties of $\mathrm{CeMnO}_{3}$ perovskite in lithium-ion batteries were investigated. $\mathrm{CeMnO}_{3}$ anode exhibited a discharge capacity of $2159 \mathrm{~mA} \mathrm{~h} \mathrm{~g}{ }^{-1}$ with a coulombic efficiency of $93.79 \%$. A high reversible capacity of $395 \mathrm{~mA} \mathrm{~h} \mathrm{~g}^{-1}$ at $200 \mathrm{~mA} \mathrm{~g}{ }^{-1}$ for $\mathrm{CeMnO}_{3}$ can be obtained even at a high discharge rate of $1000 \mathrm{~mA} \mathrm{~g}^{-1}$ after 60 cycles. This study provides the feasibility of perovskite-type $\mathrm{CeMnO}_{3}$ nanofibers for the application into lithium-ion batteries. This result opens a new path for a more efficient and convenient chemical storage method in the near future. 


\section{Conflicts of interest}

There are no conflicts to declare.

\section{Acknowledgements}

This work was financially supported by the Doctoral Scientific Research Foundation of Inner Mongolia University for Nationalities (Project No: BS456), and the Scientific Research Program of Inner Mongolia University for Nationalities (Project No: NMDYB19045). The National Natural Science Foundation of China (21961024, 21961025), Inner Mongolia Natural Science Foundation (2018JQ05). Supported by Incentive Funding from Nano Innovation Institute (NII) of Inner Mongolia University for Nationalities (IMUN). Inner Mongolia Autonomous Region Funding Project for Science \& Technology Achievement Transformation (CGZH2018156). Inner Mongolia Autonomous Region Incentive Funding Guided Project for Science \& Technology Innovation (2016). Tongliao Funding Project for Application Technology Research \& Development (2017).

\section{References}

1 A. Fotouhi, D. J. Auger, K. Propp, S. Longo and M. Wild, A review on electric vehicle battery modelling: from lithiumion toward lithium-sulphur, Renewable Sustainable Energy Rev., 2016, 56, 1008-1021.

2 J. Ma, F. Yu, Z. Wen, M. Yang, H. Zhou, C. Li, L. Jin, L. Zhou, L. Chen, Z. Yuan and J. Chen, A facile one-pot method for synthesis of low-cost iron oxide/activated carbon nanotube electrode materials for lithium-ion batteries, Dalton Trans., 2013, 42, 1356-1359.

3 Y. Zhao, X. Li, B. Yan, D. J. Li, S. Lawes and X. L. Sun, Significant impact of 2D graphene nanosheets on large volume change tin-based anodes in lithium-ion batteries: a review, J. Power Sources, 2015, 274, 869-884.

4 Y. Deng, C. Fang and G. Chen, The developments of $\mathrm{SnO}_{2} /$ graphene nanocomposites as anode materials for high performance lithium ion batteries: a review, J. Power Sources, 2016, 304, 81-101.

5 N. Nitta, F. Wu, J. T. Lee and G. Yushin, Li-ion battery materials: present and future, Mater. Today, 2015, 18, 252264.

6 W. Shi, J. Mao, X. Xu, W. Liu, L. Zhang, X. Cao and X. Lu, An ultra-dense $\mathrm{NiS}_{2} /$ reduced graphene oxide composite cathode for high-volumetric/gravimetric energy density nickel-zinc batteries, J. Mater. Chem. A, 2019, 7, 15654-15661.

7 L. Zhang, W. Liu, W. Shi, X. Xu, J. Mao, P. Li, C. Ye, R. Yin, S. Ye, X. Liu, X. Cao and C. Gao, Boosting lithium storage properties of MOF derivatives through a wet-spinning assembled fiber strategy, Chem.-Eur. J., 2018, 24(52), 13792-13799.

8 W. Hong, P. Ge, Y. Jiang, L. Yang, Y. Tian, G. Zou, X. Cao, H. Hou and X. Ji, Yolk-shell structured bismuth@N-doped carbon anode for lithium-ion battery with high volumetric capacity, ACS Appl. Mater. Interfaces, 2019, 11(11), 1082910840.
9 W. Liu, R. Yin, X. Xu, L. Zhang, W. Shi and X. Cao, Structural engineering of low-dimensional metal-organic frameworks: synthesis, properties, and applications, Adv. Sci., 2019, 1802373.

10 Y. Jin, B. Zhu, Z. Lu, N. Liu and J. Zhu, Challenges and recent progress in the development of Si anodes for lithium-ion battery, Adv. Energy Mater., 2017, 7, 1700715.

11 Q. Xu, J. Y. Li, Y. X. Yin, Y. M. Kong, Y. G. Guo and L. J. Wang, Nano/micro-structured $\mathrm{Si} / \mathrm{C}$ anodes with high initial coulombic efficiency in Li-ion batteries, Chem.-Asian J., 2016, 11, 1205-1209.

12 D. A. Agyeman, K. Song, G. H. Lee, M. Park and Y. M. Kang, Carbon-coated Si nanoparticles anchored between reduced graphene oxides as an extremely reversible anode material for high energy-density Li-ion battery, Adv. Energy Mater., 2016, 6, 1600904.

13 S. H. Cho, J. W. Jung, C. Kim and I. D. Kim, Rational design of 1-D $\mathrm{Co}_{3} \mathrm{O}_{4}$ nanofibers@low content graphene composite anode for high performance Li-ion batteries, Sci. Rep., 2017, 7, 45105.

14 H. Zhou, L. Zhang, D. Zhang, S. Chen, P. R. Coxon, X. He, M. Coto, H. K. Kim, K. Xi and S. Ding, A universal synthetic route to carbon nanotube/transition metal oxide nano-composites for lithium ion batteries and electrochemical capacitors, Sci. Rep., 2016, 6, 37752.

15 Y. Li, X. Hou, Y. Li, Q. Ru, S. Hu and K. Lam, The design and synthesis of polyhedral Ti-doped $\mathrm{Co}_{3} \mathrm{O}_{4}$ with enhanced lithium-storage properties for Li-ion batteries, J. Mater. Sci.: Mater. Electron., 2016, 27, 11439-11446.

16 L. Liu, L. Mou, J. Yu and S. Chen, Urchin-like CoO-C micro/ nano hierarchical structures as high performance anode materials for Li-ion batteries, RSC Adv., 2017, 7, 2637-2643.

17 J. Guo, Y. Yang, W. Yu, X. Dong, J. Wang, G. Liu and T. Wang, Synthesis of $\alpha-\mathrm{Fe}_{2} \mathrm{O}_{3}, \mathrm{Fe}_{3} \mathrm{O}_{4}$ and $\mathrm{Fe}_{2} \mathrm{~N}$ magnetic hollow nanofibers as anode materials for Li-ion batteries, $R S C$ Adv., 2016, 6, 111447-111456.

18 J. H. Kim, Y. J. Hong, Y. C. Kang, Y. J. Choi and Y. S. Kim, Superior electrochemical properties of $\alpha-\mathrm{Fe}_{2} \mathrm{O}_{3}$ nanofibers with a porous core/dense shell structure formed from iron acetylacetonate-polyvinylpyrrolidone composite fibers, Electrochim. Acta, 2015, 154, 211-218.

19 U. Boesenberg, M. A. Marcus, A. K. Shukla, T. Yi, E. McDermott, P. F. Teh, M. Srinivasan, A. Moewes and J. Cabana, Asymmetric pathways in the electrochemical conversion reaction of $\mathrm{NiO}$ as battery electrode with high storage capacity, Sci. Rep., 2014, 4, 7133.

20 H. Lai, Q. Wu, J. Zhao, L. Shang, H. Li, R. Che, Z. Lyu, J. Xiong, L. Yang, X. Wang and Z. Hu, Mesostructured NiO/ $\mathrm{Ni}$ composites for high-performance electrochemical energy storage, Energy Environ. Sci., 2016, 9, 2053-2060.

21 S. H. Park and W. J. Lee, Hierarchically mesoporous carbon nanofiber $/ \mathrm{Mn}_{3} \mathrm{O}_{4}$ coaxial nanocables as anodes in lithium ion batteries, J. Power Sources, 2015, 281, 301-309.

22 H. Liu, Z. H. Li, Y. R. Liang, R. W. Fu and D. C. Wu, Facile synthesis of $\mathrm{MnO}$ multi-core@ nitrogen-doped carbon shell nanoparticles for high performance lithium-ion battery anodes, Carbon, 2015, 84, 419-425. 
23 J. Z. Zhao, Z. L. Tao, J. Liang and J. Chen, Facile synthesis of nanoporous $\gamma-\mathrm{MnO}_{2}$ structures and their application in rechargeable Li-ion batteries, Cryst. Growth Des., 2008, 8, 2799-2805.

24 C. Yan, G. Chen, X. Zhou, J. Sun and C. Lv, Template-based engineering of carbon-doped $\mathrm{Co}_{3} \mathrm{O}_{4}$ hollow nanofibers as anode materials for lithium-ion batteries, Adv. Funct. Mater., 2016, 26, 1428-1436.

25 S. Abouali, M. Akbari Garakani, B. Zhang, H. Luo, Z. L. Xu, J. Q. Huang, J. Huang and J. K. Kim, $\mathrm{Co}_{3} \mathrm{O}_{4} /$ porous electrospun carbon nanofibers as anodes for high performance Li-ion batteries, J. Mater. Chem. A, 2014, 2, 16939-16944.

26 X. Rui, H. Tan, D. Sim, W. Liu, C. Xu, H. H. Hng, R. Yazami, T. M. Lim and Q. Yan, Template-free synthesis of urchin-like $\mathrm{Co}_{3} \mathrm{O}_{4}$ hollow spheres with good lithium storage properties, J. Power Sources, 2013, 222, 97-102.

27 L. Li, A. R. O. Raji and J. M. Tour, Graphene-wrapped $\mathrm{MnO}_{2}$ graphene nanoribbons as anode materials for highperformance lithium ion batteries, Adv. Mater., 2013, 25, 6298-6302.

28 Y. Wu, X. Li, Q. Xiao, G. Lie, Z. Lie and J. Guan, The coaxial $\mathrm{MnO}_{2} / \mathrm{CNTs}$ nanocomposite freestanding membrane on SSM substrate as anode materials in high performance lithium ion batteries, J. Electroanal. Chem., 2019, 834, 161166.

29 Z. Cao, X. Chen, L. Xing, Y. Liao, M. Xu, X. Li, X. Liu and W. Li, Nano- $\mathrm{MnO}_{2} @ \mathrm{TiO}_{2}$ microspheres: a novel structure and excellent performance as anode of lithium-ion batteries, J. Power Sources, 2018, 379, 174-181.

30 R. Saravanan, S. Agarwal, V. K. M. M. Khan, F. Gracia, E. Mosquera, V. Narayanan and A. Stephen, Line defect $\mathrm{Ce}^{3+}$ induced $\mathrm{Ag} / \mathrm{CeO}_{2} / \mathrm{ZnO}$ nanostructure for visible-light photocatalytic activity, J. Photochem. Photobiol., A, 2018, 353, 499-506.

31 D. Xiao, C. Lu, C. Chen and S. Yuan, $\mathrm{CeO}_{2}$-webbed carbon nanotubes as a highly efficient sulfur host for lithiumsulfur batteries, Energy Storage Mater., 2018, 10, 216-222.

32 Q. Hao, G. Cui, Y. Tian, T. Tan and Y. Zhang, Threedimensional $\mathrm{S} / \mathrm{CeO}_{2} / \mathrm{rGO}$ composites as cathode materials for lithium-sulfur batteries, Materials, 2018, 11, 1720.

33 M. Li, X. Fan, X. Xiao, X. Huang, Y. Jiang and L. Chen, Ternary perovskite nickel titanate/reduced graphene oxide nano-composite with improved lithium storage properties, RSC Adv., 2016, 6, 61312-61318.

34 C. Yuan, H. Wang, J. Liu, Q. Wu, Q. Duan and Y. Li, Facile synthesis of $\mathrm{Co}_{3} \mathrm{O}_{4}-\mathrm{CeO}_{2}$ composite oxide nanotubes and their multifunctional applications for lithium ion batteries and CO oxidation, J. Colloid Interface Sci., 2017, 494, 274281.

35 S. Phokha, S. Hunpratub, N. Chanlek, S. Sonsupap and S. Maensiri, Synthesis, characterization and electrochemical performance of carbo/Ni-doped $\mathrm{CeO}_{2}$ composites, J. Alloys Compd., 2018, 750, 788-797.

36 B. G. S. Raj, A. M. Asiri, J. J. Wu and S. Anandan, Synthesis of $\mathrm{Mn}_{3} \mathrm{O}_{4}$ nanoparticles via chemical precipitation approach for supercapacitor application, J. Alloys Compd., 2015, 636, 234-240.

37 S. Zhang, Y. Zhao, M. D. Somoano, J. Yang and J. Zhang, Synergistic mercury removal over the $\mathrm{CeMnO}_{3}$ perovskite structure oxide as an SCR catalyst from coal combustion flue gas, Energy Fuels, 2018, 32(11), 11785-11795.

38 H. Yi, J. Xu, X. Tang, S. Zhao, Y. Zhang, Z. Yang, J. Wu, X. Meng, J. Meng, H. Yan and Q. Li, Novel synthesis of Pd$\mathrm{CeMnO}_{3}$ perovskite based on unique ultrasonic intervention from combination of Sol-Gel and impregnation method for low temperature efficient oxidation of benzene vapour, Ultrason. Sonochem., 2018, 48, 418-423.

39 H. Li, G. Lu, Q. Dai, Y. Wang, Y. Guo and Y. Guo, Efficient low-temperature catalytic combustion of trichloroethylene over flower-like mesoporous Mn-doped $\mathrm{CeO}_{2}$ microspheres, Appl. Catal., B, 2011, 102, 475-483.

40 J. Bhagwan, A. Sahoo, K. L. Yadav and Y. Sharm, Nanofibers of spinel-CdMn $\mathrm{O}_{4}$ : a new and high performance material for supercapacitor and Li-ion batteries, J. Alloys Compd., 2017, 703, 86-95.

41 C. Li, R. Chen, X. Zhang, S. Shu, J. Xiong, Y. Zheng and W. Dong, Electrospinning of $\mathrm{CeO}_{2}-\mathrm{ZnO}$ composite nanofibers and their photocatalytic property, Mater. Lett., 2011, 65, 1327-1330.

42 Y. Zhang, J. Li, Q. Li, L. Zhu, X. Liu, X. Zhong, J. Meng and X. Cao, Preparation of $\mathrm{CeO}_{2}-\mathrm{ZrO}_{2}$ ceramic fibers by electrospinning, J. Colloid Interface Sci., 2007, 307, 567-571.

$43 \mathrm{X} . \mathrm{Hu}, \mathrm{Y} . \mathrm{Ji}, \mathrm{M}$. Wang, F. Miao, H. Ma, H. Shen and N. Jia, Water-Soluble and Biocompatible MnO@PVP Nanoparticles for MR Imaging In Vitro and In Vivo, $J$. Biomed. Nanotechnol., 2013, 9, 976-984.

44 Q. Cui, X. Dong, J. Wang and M. Li, Direct fabrication of cerium oxide hollow nanofibers by electrospinning, J. Rare Earths, 2008, 26, 664-669.

45 Z. A. Elsiddig, D. Wang, H. Xu, W. Zhang, T. Zhang, P. Zhang, W. Tian, Z. Sun and J. Chen, Three-dimensional nitrogendoped graphene wrapped $\mathrm{LaMnO}_{3}$ nanocomposites as high-performance supercapacitor electrodes, J. Alloys Compd., 2018, 740, 148-155.

46 A. Younis, D. W. Chu and S. A. Li, Oxygen level: the dominant of resistive switching characteristics in cerium oxide thin films, J. Phys. D: Appl. Phys., 2012, 45, 355101.

47 L. R. Shah, B. Ali, H. Zhu, W. G. Wang, Y. Q. Song, H. W. Zhang, S. I. Shah and J. Q. Xiao, Detailed study on the role of oxygen vacancies in structural, magnetic and transport behavior of magnetic insulator: $\mathrm{Co}-\mathrm{CeO}_{2}, \mathrm{~J}$. Phys.: Condens. Matter, 2009, 21, 486004.

48 M. Kumar, J. H. Yun, V. Bhatt, B. Singh, J. Kim, J. S. Kim, B. S. Kim and C. Y. Lee, Role of $\mathrm{Ce}^{3+}$ valence state and surface oxygen vacancies on enhanced electrochemical performance of single step solvothermally synthesized $\mathrm{CeO}_{2}$ nanoparticles, Electrochim. Acta, 2018, 284, 709-720.

49 D. R. Mullins, S. H. Overbury and D. R. Huntley, Electron spectroscopy of single crystal and polycrystalline cerium oxide surfaces, Surf. Sci., 1998, 409, 307-319. 
50 A. Krittayavathananon, T. Pettong, P. Kidkhunthod and M. Sawangphruk, Insight into the charge storage mechanism and capacity retention fading of $\mathrm{MnCo}_{2} \mathrm{O}_{4}$ used as supercapacitor electrodes, Electrochim. Acta, 2017, 258, 1008-1015.

51 G. Praline, B. E. Koel, R. L Hance, H. Lee and J. M. White, Xray photoelectron study of the reaction of oxygen with cerium, J. Electron Spectrosc. Relat. Phenom., 1980, 21, 17-30.

52 C. Wang, D. L. Wang, Q. M. Wang and H. J. Chen, Fabrication and lithium storage performance of threedimensional porous $\mathrm{NiO}$ as anode for lithium-ion battery, J. Power Sources, 2010, 195, 7432-7437.

53 J. Wang, D. Jin, R. Zhou, X. Li, X. Liu, C. Shen, K. Xie, B. Li, F. Kang and B. Wei, Highly flexible graphene $/ \mathrm{Mn}_{3} \mathrm{O}_{4}$ nanocomposite membrane as advanced anodes for $\mathrm{Li}$-ion batteries, ACS Nano, 2016, 10, 6227-6234.

54 X. Gu, J. Yue, L. Li, H. Xue, J. Yang and X. Zhao, General synthesis of $\mathrm{MnO}_{\mathrm{x}}\left(\mathrm{MnO}_{2}, \mathrm{Mn}_{2} \mathrm{O}_{3}, \mathrm{Mn}_{3} \mathrm{O}_{4}, \mathrm{MnO}\right)$ hierarchical microspheres as lithium-ion battery anodes, Electrochim. Acta, 2015, 184, 250-256.

$55 \mathrm{X} . \mathrm{Xu}, \mathrm{R}$. Cao, S. Jeong and J. Cho, Spindle-like mesoporous $\alpha-\mathrm{Fe}_{2} \mathrm{O}_{3}$ anode material prepared from MOF template for high-rate lithium batteries, Nano Lett., 2012, 12, 4988-4991.
56 C. Peng, B. Chen, Y. Qin, S. Yang, C. Li, Y. Zuo, S. Liu and Y. Yang, Facile ultrasonic synthesis of CoO quantum dot/ graphene nanosheet composites with high lithium storage capacity, ACS Nano, 2012, 6, 1074-1081.

$57 \mathrm{H}$. Liu and Q. Le, Synthesis and performance of cerium oxide as anode materials for lithium ion batteries by a chemical precipitation method, J. Alloys Compd., 2016, 669, 1-7.

58 Y. Cho, P. Oh and J. Cho, A new type of protective surface layer for high-capacity Ni-based cathode materials: nanoscaled surface pillaring layer, Nano Lett., 2013, 13, 1145-1152.

59 K. B. Hatzell, M. Beidaghi, J. W. Campos, C. R. Dennison, E. C. Kumbur and Y. Gogotsi, A high performance pseudocapacitive suspension electrode for the electrochemical flow capacitor, Electrochim. Acta, 2013, 111, 888-897.

60 C. Hua, X. Fang, Z. Wang and L. Chen, Lithium storage in perovskite lithium lanthanum titanate, Electrochem. Commun., 2013, 32, 5-8.

61 Y. Wang, X. Wen, J. Chen and S. Wang, Foamed mesoporous carbon/silicon composite nanofiber anode for lithium ion batteries, J. Power Sources, 2015, 281, 285-292. 